\title{
ANALYSIS OF HEAT RELEASE RATE IN ENGINE ROOM FIRES OF 300 GT FERRY RO-RO PASSENGER BY USING WATER MIST SYSTEM AND $\mathrm{CO}_{2}$ SYSTEM
}

\author{
Wira Setiawan', Distyan Kotanjungan ${ }^{1}$ \\ ${ }^{1}$ Kalimantan Institute of Technology \\ e-mail:wira@lecturer.itk.ac.id
}

\begin{abstract}
Based on statistical data in recent years, there are still quite several ship accidents due to fires, including on passenger ships. The water mist system is a fire suppression system that allows it to be used in the engine room with the advantage that it can keep the heat production rate low during the extinguishing process and can be operated earlier than the $\mathrm{CO}_{2}$ system. The research is conducted by using a dynamic fire simulator in the engine room of a 300 GT ferry ro-ro passenger to compare the heat release rate of fire without an extinguishing system, an existing $\mathrm{CO}_{2}$ system, and a water mist system. The result shows that the $\mathrm{CO}_{2}$ fire suppression system reduces the heat release rate more rapidly to the decay phase at 375 seconds, while the water mist takes more than 900 seconds. However, the fully developed phase of the water mist suppression system occurs more quickly than $\mathrm{CO}_{2}$ because the sprinklers are activated shortly after a fire occurs. Unlike water mist, the $\mathrm{CO}_{2}$ system is activated at 60 seconds so that the pre-combustion, growth, flashover, and fully developed phases are at the same HRR and time as the natural one.
\end{abstract}

Keywords: Heat Release Rate; Water mist System; $\mathrm{CO}_{2}$ System; Fire on Ship; Fire Dynamics

Received: 2021-06-22; Revised: 2021-07-24; Accepted: 2021-08-02

\section{INTRODUCTION}

Fire is one of the ship accidents that have the worst impact compared to other types of accidents. The risk of fatalities caused can reach $132 \%$ greater than other types of accidents such as grounding, collision, and sinking [1]. Relatively more victims are death because fire conditions can cause panic, especially if there is no preparation in dealing with emergency conditions [2]. The cause of ship fires can be initiated by human error, damage to mechanical and electrical systems, thermal reactions, and other things [3]. Among the various types of ships, the Ferry Ro-Ro/Passenger ship is the one that experiences fires the most, and the risk can even be doubled compared to other types of ships [4].

Fires on ships do not just happen instantly, but there are several stages of the cause of the fire. Fire begins with the presence of ignition. The fire can grow rapidly or slowly depending on the conditions of the room and combustion which is called the growth stage of the fire. The next step is the flashover phase which is characterized by the presence of a large flame with a temperature of around $500^{\circ} \mathrm{C}$ to $600^{\circ} \mathrm{C}$. There is a firing peak in the fully developed phase where the highest temperature during the fire will occur. Once it reaches its peak, the fuel begins to deplete and lowers combustion. This phase is called fire decay where the fire will ignite naturally because there is no oxygen or fuel anymore for the combustion process to sustain [5].

In addition to temperature, mass loss, gas release, and release of kinetic energy material, fire indicators are more precise and important to express in terms of heat release rate. This parameter indicates how much and how fast energy is released in a unit area per unit time [6]. 


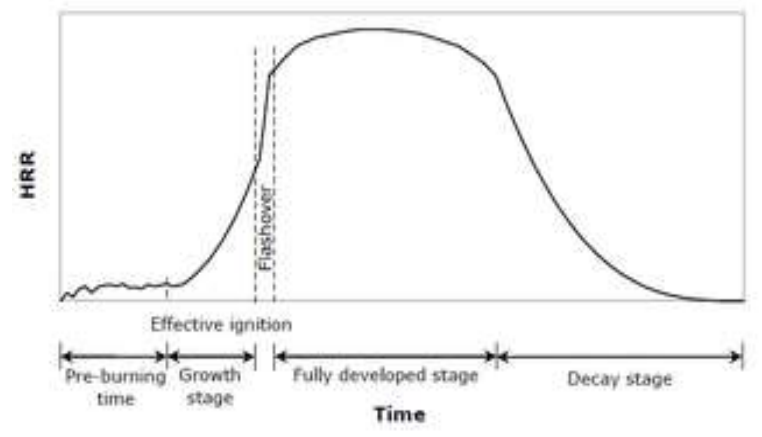

Figure 1. Fire Stage of Fire Development.

The engine room is one of the compartments that have a high fire risk. This is because this room has many mechanical and electrical components including fuel that produces heat. When the surface of a thermal object interacts with the fuel, a fire will easily occur [7],[8]. However, fire and heat were not the only cause of death of the crew but also due to the presence of smoke and gas [9].

The engine room also has a risk of re-fire if the ventilation openings supply air when the fire has not been completely extinguished [10]. Fires in the engine room can also cause other accidents such as grounding and collisions because the engine stops working [11]. The $\mathrm{CO}_{2}$ system is most widely used for extinguishing indoor fires because it is not corrosive, does not damage mechanical and electrical components, leaves no residue after extinguishing media, and effectively breaks the fire triangle because it has a density of 1.5 times greater than air. However, the $\mathrm{CO}_{2}$ system also has drawbacks that can result in loss of consciousness if inhaled, a fairly low cooling effect, and a delay in the time required to assist personnel as stipulated in the Fire Safety System (FSS) code [12].

One of the fires extinguishing systems on ships that can be used as an alternative for fires in the engine room which is currently being developed, is the water mist system. The water mist system is an extinguishing system using water vapor (mist) media and can be used for type B fires caused by fuel oil [13]. Among the advantages of water mist are that the substance used is not harmful and the activation times are shorter than $\mathrm{CO}_{2}$ [14]. Even the water mist system can access class $A, B, C$, and $K$ fires with an effective temperature reduction process and less water usage [15].

The effectiveness of reducing the temperature occurs because most of the heat that arises can be absorbed by water droplets [16]. Unlike the sprinkling system, the water mist system has a droplet size at its operating pressure which is not more than 1000 microns and will eventually form water vapor. A similar finding was also reported by Butz and Marmaro that the water mist system could work effectively with larger droplet size and flow rate settings [17]. Meanwhile, according to Liu and Kim, in addition to droplet size, flux density and spray dynamics also make a major contribution to the effectiveness of the water mist system [18].

Based on the NFPA 450 standard regulation of the water mist fire extinguishing system, the water mist extinguishing system can be used for fires on ships, especially in special spaces such as engine rooms. In addition, as an alternative to halon, International Maritime Organization (IMO) also allows the use of water mist with several principal requirements. For example, it can be used as quickly as possible with a minimum of 30 minutes of extinction time to prevent possible reignition of fire [19]. The feasibility of water mist was also proven by experiments in full-scale trials in a large test facility such as those carried out by Bill et al [20].

The purpose of this study is to analyze the effectiveness of the $\mathrm{CO}_{2}$ system compared to the water mist system and to provide initial information related to the characteristics of fires.

\section{METHODS}

This study aims to compare the effectiveness of the water mist and $\mathrm{CO}_{2}$ fire extinguishing system in the engine room of the 300 GT Ferry Ro-Ro ship with the same number of sprinkler heads. The method used is large eddy simulation (LES) using a fire dynamics simulator program on the Navier-Stokes flow equation and the law of conservation of energy as follows [21].

$Q={ }_{\dot{\mathrm{m}} A} C_{p}\left(\mathrm{~T}_{s}-\mathrm{T}_{A}\right)$

where $Q$ is heat energy per unit area $\mathrm{kW} / \mathrm{m}^{2}, \quad \dot{\mathrm{m}} A$ is mass flow rate $\mathrm{kg} / \mathrm{s}, C_{p}$ is Specific heat $\mathrm{kJ} / \mathrm{kgK}$, $T_{S}$ is smoke temperature $K$ and $T_{A}$ is ambient temperature $\mathrm{K}$. While the heat release rate equation can be stated based on the following equation.

$\boldsymbol{Q}=\dot{\mathrm{m}}^{\prime \prime} \boldsymbol{A}_{\boldsymbol{f}} \Delta \boldsymbol{H}_{\text {eff }}$

where $\boldsymbol{Q}$ is the total heat release rate per unit area $\mathrm{kW} / \mathrm{m}^{2}, \dot{\mathrm{m}}^{\prime \prime}$ is the mass loss rate per unit area $\mathrm{kg} / \mathrm{m}^{2} \mathrm{~s}, A_{f}$ is the horizontal burning area of the fuel $\mathrm{m}^{2}$ while $\Delta H_{\text {eff }}$ is the effective heat of combustion $\mathrm{kJ} / \mathrm{kg}$. 
This program can model fires based on the characteristics of the fire source, material properties, and fire extinguishing properties to calculate the energy generated due to fires at a certain time unit.

In this study, the ship used is a 300 GT ro-ro ferry with the following main dimensions:

Table 1. Ship's main dimensions

\begin{tabular}{ll}
\hline \multicolumn{1}{c}{ Item } & \multicolumn{1}{c}{ Value } \\
\hline Length Overall (LoA) & $39.38 \mathrm{~m}$ \\
Length Perpendicular (Lpp) & $34.5 \mathrm{~m}$ \\
Breadth (B) & $11.0 \mathrm{~m}$ \\
Depth (D) & $3.3 \mathrm{~m}$ \\
Draught (T) & $2.3 \mathrm{~m}$ \\
\hline
\end{tabular}

This ship is equipped with four fire extinguishing systems namely the main fire hydrant in all decks, a water sprinkler system in the accommodation room, a water drencher incar deck and a $\mathrm{CO}_{2}$ suppression system in the engine room as illustrated in Figure 2 below.

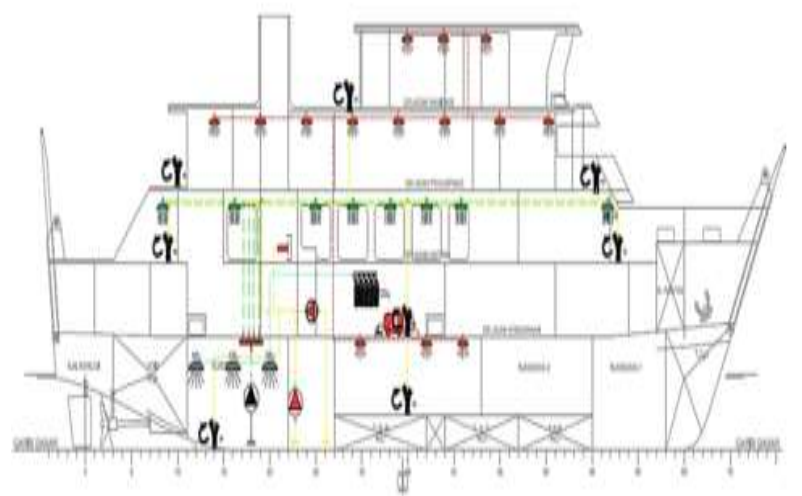

Figure 2. Profile View of Fire Fighting Arrangement of Ferry Ro-Ro 300 GT.

The engine room is modeled referring to Figure 3 with a length of 12 meters and a width of 11 meters. The compartment has two access stairs to go in and go out of the room. Besides that there are also exhaust gas pipes and trunk ventilation for supply and exhaust blowers. The engine room is equipped with a $\mathrm{CO}_{2}$ extinguishing system with a total of 8 sprinkler heads located directly above the main engines and auxiliary engine. For controlling the machinery system, the engine control room is located in the forwarding of the main and auxiliary engine. It is the only compartment that is not covered by the $\mathrm{CO}_{2}$ system as recommended by rules and regulations. The result of engine room modeling is shown in Figure 4.

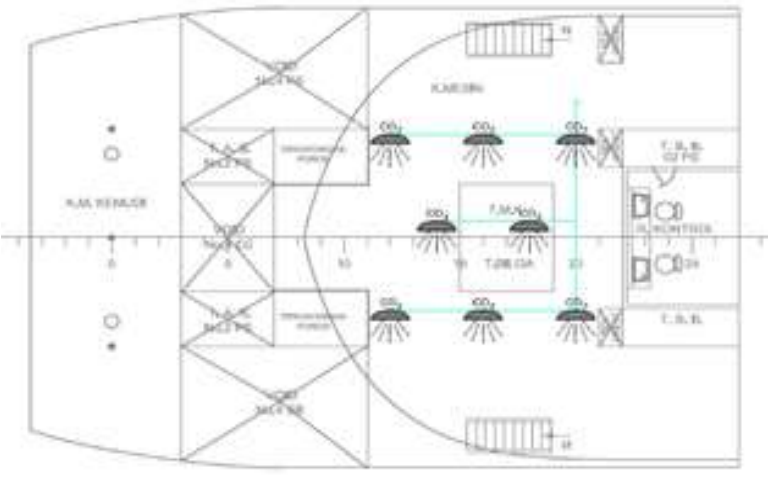

Figure 3. Plan View of $\mathrm{CO} 2$ System in Engine Room of Ferry Ro-Ro 300 GT.

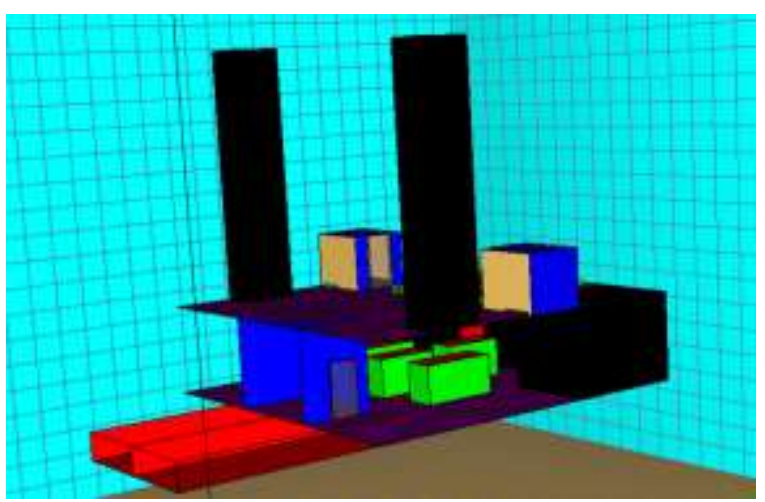

Figure 4. Engine Room Modelling.

Eight $\mathrm{CO}_{2}$ sprinkle head points are consisting of each 3 in the starboard and portside and 2 in the middle of the ship as coordinates shown in Table 2.

Table 2. $\mathrm{CO}_{2}$ sprinkle head coordinates $(\mathrm{m})$

\begin{tabular}{cccc}
\hline Sprinkler no & $\mathbf{x}$ & $\mathbf{y}$ & $\mathbf{z}$ \\
\hline 1 & 4.5 & 7.9 & 3.2 \\
2 & 4.5 & 3.7 & 3.2 \\
3 & 6.5 & 7.9 & 3.2 \\
4 & 6.5 & 3.7 & 3.2 \\
5 & 8.5 & 7.9 & 3.2 \\
6 & 8.5 & 3.7 & 3.2 \\
7 & 5.5 & 5.9 & 3.2 \\
8 & 7.5 & 5.9 & 3.2 \\
\hline
\end{tabular}

The $\mathrm{CO}_{2}$ system is widely used as an extinguisher in engine rooms because it is considered effective for fires in rooms full of fuel. The procedure carried out when a fire occurs is to close all openings, both ventilation and access to the engine room. This is done to cut off the oxygen supply as one of the elements of the fire triangle. The carbon dioxide can be sprayed in 
the engine room after a delay of 60 to 90 seconds to give the engine crew time to get out of the engine room.

In addition, to model the engine room and sprinkler points, it is also necessary to determine the properties of the extinguishing system used. For $\mathrm{CO}_{2}$, the value of mass flux is set at 100 $\mathrm{kg} / \mathrm{m}^{2} \mathrm{~s}$ that indicates that $\mathrm{CO}_{2}$ is to be injected at that rate with a radius of $\mathrm{CO}_{2}$ spherical source is $0.01 \mathrm{~m}$ and $\tau$ MF of 1.0 second means the time interval of mass flux increase.

Table 3. $\mathrm{CO}_{2}$ Properties

\begin{tabular}{ll}
\hline \multicolumn{1}{c}{ Item } & \multicolumn{1}{c}{ Value } \\
\hline Mass Flux & $100 \mathrm{~kg} / \mathrm{m}^{2} \mathrm{~s}$ \\
Radius & $0.01 \mathrm{~m}$ \\
$\tau$ MF & $1.0 \mathrm{~s}$ \\
\hline
\end{tabular}

While the properties of the water mist used include operational pressure, droplet diameter, particles per second, droplet velocity, $\mathrm{K}$ factor as flow coefficient of the nozzle, and spray angle as follows.

Table 4. Water Mist Properties

\begin{tabular}{ll}
\hline \multicolumn{1}{c}{ Item } & \multicolumn{1}{c}{ Value } \\
\hline Operation Pressure & $34.5 \mathrm{bar}$ \\
Droplets Diameter & $300 \mu \mathrm{m}$ \\
Particle per second & 10000 \\
Velocity & $5.0 \mathrm{~m} / \mathrm{s}$ \\
K Factor & $85 \mathrm{~L} / \mathrm{min} / \mathrm{bar}^{1 / 2}$ \\
Minimum Spray Angle & $60^{\circ}$ \\
Maximum Spray Angle & $75^{\circ}$ \\
\hline
\end{tabular}

Fires originating from diesel oil assuming a fuel pipe leak occurs with fuel properties covering a molecular weight of $142 \mathrm{~g} / \mathrm{mol}$ with the formula $\mathrm{C}_{10} \mathrm{H}_{22}$ then the simulation time is set to 900 seconds.

\section{RESULTS AND DISCUSSION}

\section{Simulation Results}

Based on the simulation results, it can be seen the modeling with fire illustration is shown in Figure 5. From the figure, it can be seen that there is a fire in a room with a $\mathrm{CO}_{2}$ extinguishing system, where the sprinkler will activate at an interval of 60 seconds after the fire. When compared to a system without using an extinguishing media (natural), the first 60 seconds produces the same performance because the $\mathrm{CO}_{2}$ has been set to the set point.
After that, $\mathrm{CO}_{2}$ reacts quickly so the fire can be extinguished in 375 seconds. Previously, it was seen that the growth, flashover, and fully developed phases last quite short of less than 50 seconds at a maximum heat release rate of 1000 $\mathrm{kW} / \mathrm{m}^{2}$. The same result also occurs for natural systems. When $\mathrm{CO}_{2}$ is released after 60 seconds, then this system can move the fire to the decay phase. On the other hand, the natural system shows an HRR graph that tends to be constant at a maximum heat release of around $4500 \mathrm{~kW} / \mathrm{m}^{2}$ until the end of the simulation for 900 seconds.

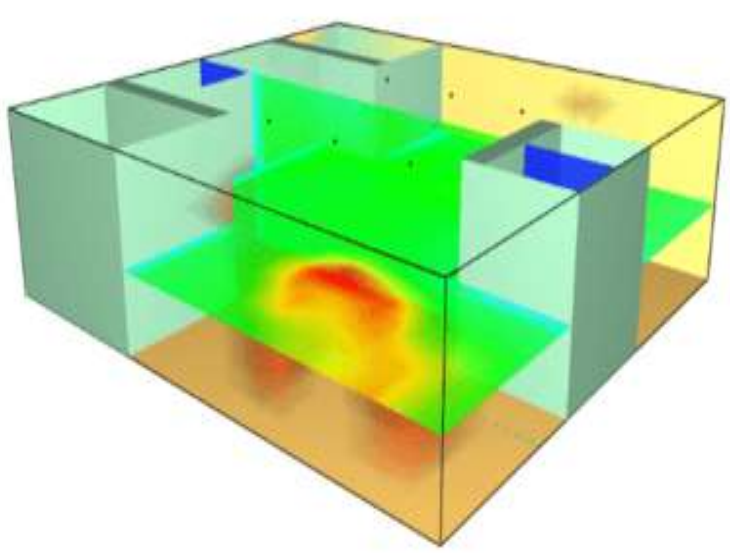

Figure 5. Fire in Engine Room with $8 \mathrm{CO}_{2}$ Sprinkler Units.

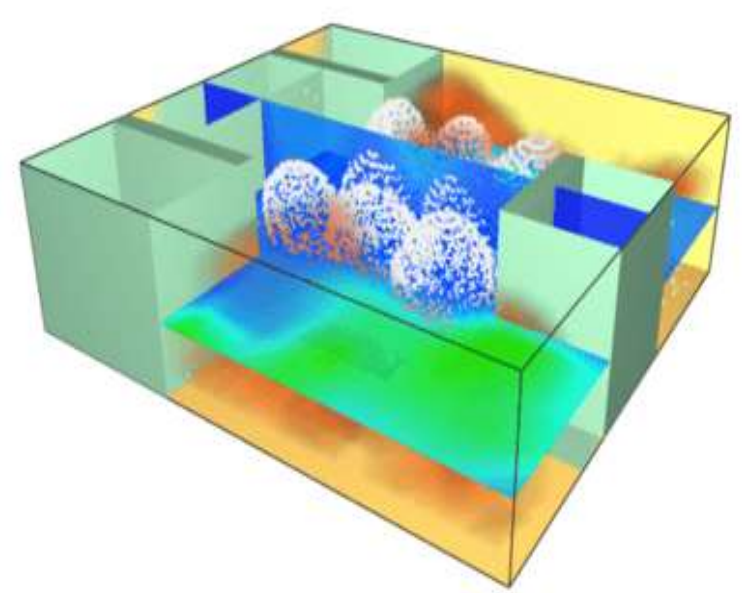

Figure 6. Fire in Engine Room with 8 Water Mist Sprinkler Units. 

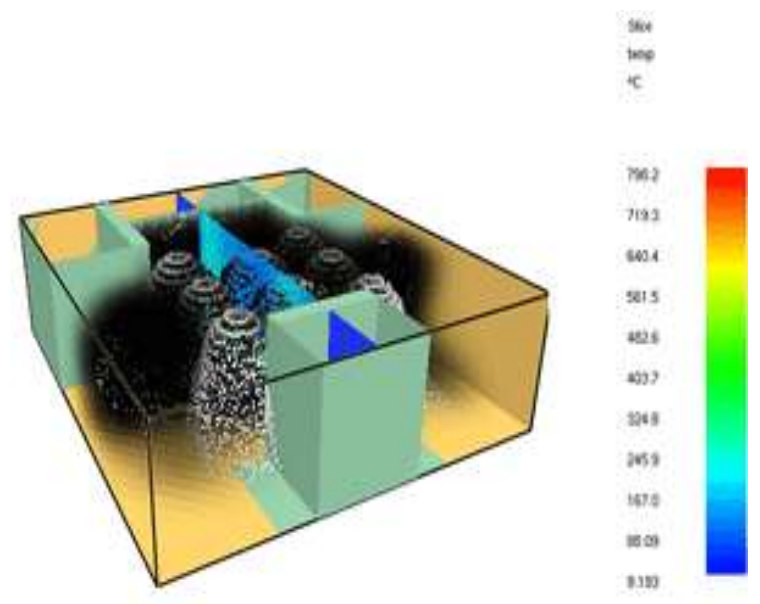

Figure 7. Smoke spread in Engine Room with 8 Water Mist Sprinkler Units.

Unlike the $\mathrm{CO}_{2}$, the water mist system can be released immediately without any time delay as seen in Figure 6. This results in a fasterextinguishing effect, namely at 20 seconds, the fire passes through the fully developed phase. After dropping significantly to 60 seconds, the HRR in the water mist system moves down slowly until the $900^{\text {th }}$ second reaches $212 \mathrm{~kW} / \mathrm{m}^{2}$.

The smoke spread is limited only in the engine room which is typically the same in all conditions as illustrated in Figure 7 . It is influenced by the assumption that all the openings are automatically closed when the fire occurs.

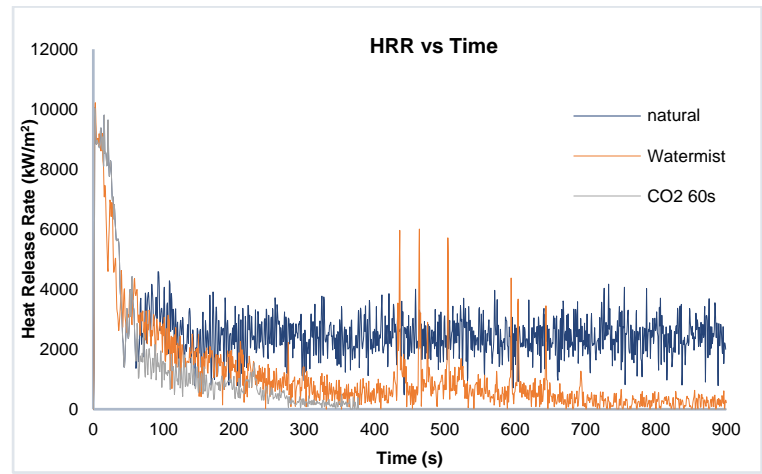

Figure 8. Comparison of HRR between natural, water mist and $\mathrm{CO}_{2}$ suppression system performance.

In addition, what is quite interesting is the occurrence of the re-ignition phenomenon which is quite short and occurs about six times at an HRR of around $6000 \mathrm{~kW} / \mathrm{m}^{2}$ and a smaller one at around $4000 \mathrm{~kW} / \mathrm{m}^{2}$. After 650 seconds, the HRR tends to stabilize at $200-300 \mathrm{~kW} / \mathrm{m}^{2}$ even though the fire has not been completely extinguished.
From the comparison of HRR in Figure 8, it is clear that at the typical properties, the $\mathrm{CO}_{2}$ system still looks more effective in suppressing the rate of fire growth compared to water mist. Moreover, in the simulation without a fire extinguisher, the fire is still burning at an HRR of around $4000-5000 \mathrm{~kW} / \mathrm{m}^{2}$ at 900 seconds. This also indicates that the failure of the extinguishing system in the engine room can result in the spread of fire in other compartments on the ship.

\section{Discussion}

Fire on ships is an interesting object to study because there are quite some variables that can be used. The choice of the $\mathrm{CO}_{2}$ system still shows the advantages of being used on ships although this study requires validation in a full-scale test to view and measure fire parameters using two different systems in an iterative experiment [20].

The use of $\mathrm{CO}_{2}$ and water mist each has advantages and disadvantages, both technical and non-technical. Water mist is a suitable medium to use because it does not contain toxic, although in the characteristics of this study it requires a longer extinguishing time than $\mathrm{CO}_{2}$.

The performance of a water mist fire system can be improved by making various changes to the operational pressure parameters, $\mathrm{K}$ factor, spray angle, particles per second, droplet diameter to sprinkler heads. In addition, it is necessary to identify the phenomenon of reignition of the fire so that the extinguishing stage can take place once (one process) in the entire accident.

To develop the research, it is necessary to carry out variations and deeper studies on several parameters to explore more detail in the effectiveness of these two systems. For example, as done by Pitana et al in analyzing ship shipping routes. This can also be done in the engine room of a 300 GT ship to calculate crew evacuation time [2]. In addition, several variations of ventilation in the engine room can also be made, such as natural and forced closed ventilation [14]. This will affect the time of firefighting on board and have similarities with actual conditions. Likewise, the properties of water mist such as droplet size can be reduced, which means better cooling efficiency [13] [22]. On the other hand, the pressure parameter can also be considered because it affects the particle size, velocity and momentum [13]. Setting the spray angle also affects the temperature and concentration of $\mathrm{O}_{2}$ and $\mathrm{CO}_{2}$ gases [23]. 


\section{CONCLUSION}

In this study, a comparison of $\mathrm{CO}_{2}$ and water mist fire extinguishing systems was carried out and the following conclusions were obtained:

1. The $\mathrm{CO}_{2}$ and water mist fire suppression systems pass through pre-combustion, growth, flashover, fully developed and decay stages. Likewise, for fires without an extinguishing system even though in the 900second simulation it has not yet occurred the decay phase.

2. The $\mathrm{CO}_{2}$ fire suppression system reduces the rate of heat release more rapidly to the decay phase at 375 seconds than the water mist that takes more than 900 seconds.

3. The fully developed phase of the water mist suppression system occurs more quickly than $\mathrm{CO}_{2}$ because the sprinklers are activated shortly after a fire occurs. Unlike the $\mathrm{CO} 2$ system which is activated 60 seconds later so that the pre-combustion, growth, flashover and full development phases are at the same HRR as the natural one during that 1 minute.

\section{AUTHOR INFORMATION}

\section{Corresponding Authors}

Email:wira@lecturer.itk.ac.id

Phone: +62 81543126001

\section{Author Contributions}

First Author and Second Author have contributed equally to this work.

\section{ACKNOWLEDGMENTS}

The authors would like to thank the National Institute of Standards and Technology for providing an open-source software of Fire Dynamics Simulator.

\section{REFERENCES}

[1] J. Weng and D. Yang, "Investigation of shipping accident injury severity and mortality," Accident Analysis \& Prevention, vol. 76, pp. 92-101, Mar. 2015, DOI: 10.1016/j.aap.2015.01.002.

[2] T. Pitana, M. B. Zaman, D. C. K. Perdana, and A. Nurwahyudi, "Analysis Evacuation Route for KM Zahro Express on Fire Condition using Agent - Based Modeling and
Fire Dynamics Simulator," International Journal of Marine Engineering Innovation and Research, vol. 1, p. 8, Sep. 2017.

[3] T. Baalisampang, R. Abbassi, V. Garaniya, F. Khan, and M. Dadashzadeh, "Review and analysis of fire and explosion accidents in maritime transportation," Ocean Engineering, vol. 158, pp. 350-366, Jun. 2018, DOI: 10.1016/j.oceaneng.2018.04.022.

[4] B. Barlas, R. Ozsoysal, E. Bayraktarkata, and O. Ozsoysal, "A study on the identification of fire Hazards on board: A case study," brod, vol. 68 , no. 4 , pp. 71-87, Dec. 2017, DOI: $10.21278 /$ brod68405.

[5] L. Staffansson, "Selecting design fires," Lund University, p. 106, 2010.

[6] "Li-Secondary Battery," in Electrochemical Power Sources: Fundamentals, Systems, and Applications, Elsevier, 2019, pp. 507629. DOI: 10.1016/B978-0-444-637772.00012-8.

[7] J. McNay, R. Puisa, and D. Vassalos, "Analysis of effectiveness of fire safety in machinery spaces," Fire Safety Journal, vol. 108 , p. 102859, Sep. 2019, DOI: 10.1016/j.firesaf.2019.102859.

[8] U. M. Ikeagwuani and G. A. John, "Safety in maritime oil sector: Content analysis of machinery space fire hazards," Safety Science, vol. 51, no. 1 , pp. 347-353, Jan. 2013, DOI: 10.1016/j.ssci.2012.08.003.

[9] L. Wang and S. Su, "Three-dimensional Numerical Simulation of Smoke Motion in Fire of the Ship Engine Room with Multilayer Structure," p. 7, 2011.

[10]J. Wang et al., "An experimental and nondimensional study on the vertical temperature distribution of a sealed ship engine room fire," Ocean Engineering, vol. 165, pp. 22-33, Oct. 2018, DOI: 10.1016/j.oceaneng.2018.07.018.

[11]R. Puisa, S. Williams, and D. Vassalos, "Towards an explanation of why onboard fires happen: The case of an engine room fire on the cruise ship 'Le Boreal,"' Applied Ocean Research, vol. 88, pp. 223-232, Jul. 2019, DOI: 10.1016/j.apor.2019.04.020.

[12] International Maritime Organization, FSS Code-international code for fire safety systems, Second Edition. London, UK: William Clowes Ltd., 2007. 
[13]I. Burch, "Water Mist for Ship Machinery Spaces," p. 38, Apr. 2006.

[14]E. A. Kolstad and B. P. Husted, "Effect of Water Mist and Ventilation on Engine Room Fire," p. 7, Jun. 2013.

[15]N. Meng, L. Hu, S. Liu, L. Wu, L. Chen, and B. Liu, "Full-scale experimental study on fire suppression performance of a designed water mist system for rescue station of long railway tunnel," Journal of Fire Sciences, vol. 30, no. 2, pp. 138-157, Mar. 2012, DOI: 10.1177/0734904111428898.

[16]E. Blanchard et al., "Experimental and Numerical Study of the Interaction Between Water Mist and Fire in an Intermediate Test Tunnel," Fire Technol, vol. 50, no. 3, pp. 565587, May 2014, DOI: 10.1007/s10694-0130323-z.

[17]B. R. James, T. Robert, and K. R. Grosskopf, "Fine Water Mists for Suppression of Class B Fuel Fires," p. 12.

[18]Zhigang Liu and A. K. Kim, "A Review of Water Mist Fire Suppression Systems-Fundamental Studies," Journal of Fire Protection Engineering, vol. 10, no. 3, pp. 32-50, Jan. 1999, DOI: $10.1177 / 104239159901000303$.
[19] International Maritime Organization, "MSC/Res. 668 Alternative arrangements for halon fire-extinguishing systems in machinery spaces and pump-rooms (MSC/Circ.728)," p. 50, 1996.

[20]R. G. Bill, R. L. Hansen, and K. Richards, "Fine-spray (water mist) protection of shipboard engine rooms," Fire Safety Journal, vol. 29, no. 4, pp. 317-336, Nov. 1997, DOI: 10.1016/S0379-7112(97)000179.

[21]K. McGrattan, S. Hostikka, R. McDermott, J. Floyd, C. Weinschenk, and K. Overholt, "Fire Dynamics Simulator User's Guide," NIST Special Publication, p. 288, Apr. 2013.

[22] M. F. Abd Rabbo, D. A. M. Ayoub, and D. M. A. Ibrahim, "Study the Effect of Water Mist Droplet Size and Nozzle Flow Rate on Fire Suppression in Hanger by Using FDS," p. 2, Apr, 2013

[23] M. F. Abd Rabbo, D. A. M. Ayoub, and D. M. A. Ibrahim, "The Effect of Water Mist Nozzle Spray Angle on Fire Suppression in Hanger by Using FDS," p. 20, Jun.2013. 